\title{
Social defeat during adolescence and adulthood differentially induce BDNF-regulated immediate early genes
}

\section{Caroline M. Coppens ${ }^{1}{ }^{*}$, Taweeporn Siripornmongcolchai ${ }^{2}$, Karin Wibrand ${ }^{2}$, Maria Nordheim Alme ${ }^{2}$, Bauke Buwalda ${ }^{1}$, Sietse F. de Boer ${ }^{1}$, Jaap M. Koolhaas ${ }^{1}$ and Clive R. Bramham ${ }^{2}$}

${ }^{1}$ Department of Behavioural Physiology, University of Groningen, Groningen, Netherlands

2 Department of Biomedicine, K. G. Jebsen Centre for Research on Neuropsychiatric Disorders, University of Bergen, Bergen, Norway

Edited by:

Sumantra "Shona" Chattarji, National Centre for Biological Sciences, India

Reviewed by:

Shane M. O'Mara, Trinity College

Dublin, Ireland

Sylvie Granon, Université Paris Sud

$X I$, France

\section{*Correspondence:}

Caroline M. Coppens, Department of Behavioural Physiology, University of Groningen, P.O. Box 11103, 9700 CC

Groningen, Netherlands.

e-mail: c.m.coppens@rug.nl
Stressful life events generally enhance the vulnerability for the development of human psychopathologies such as anxiety disorders and depression. The incidence rates of adult mental disorders steeply rises during adolescence in parallel with a structural and functional reorganization of the neural circuitry underlying stress reactivity. However, the mechanisms underlying susceptibility to stress and manifestation of mental disorders during adolescence are little understood. We hypothesized that heightened sensitivity to stress during adolescence reflects age-dependent differences in the expression of activity-dependent genes involved in synaptic plasticity. Therefore, we compared the effect of social stress during adolescence with social stress in adulthood on the expression of a panel of genes linked to induction of long-term potentiation (LTP) and brain-derived neurotrophic factor (BDNF) signaling. We show that social defeat during adolescence and adulthood differentially regulates expression of the immediate early genes BDNF, Arc, Carp, and Tieg1, as measured by qPCR in tissue lysates from prefrontal cortex, nucleus accumbens, and hippocampus. In the hippocampus, mRNA levels for all four genes were robustly elevated following social defeat in adolescence, whereas none were induced by defeat in adulthood. The relationship to coping style was also examined using adult reactive and proactive coping rats. Gene expression levels of reactive and proactive animals were similar in the prefrontal cortex and hippocampus. However, a trend toward a differential expression of BDNF and Arc mRNA in the nucleus accumbens was detected. BDNF mRNA was increased in the nucleus accumbens of proactive defeated animals, whereas the expression level in reactive defeated animals was comparable to control animals. The results demonstrate striking differences in immediate early gene expression in response to social defeat in adolescent and adult rats.

Keywords: social defeat, stress, adolescence, BDNF, synaptic plasticity, hippocampus, mesocorticolimbic system, rat

\section{INTRODUCTION}

Stressful life events generally enhance the vulnerability for the development of human psychopathologies such as anxiety disorders and depression. The majority of adult mental disorders have antecedents and precursors in adolescence. From age 15 incident rates steeply rise for anxiety disorders (Bernstein et al., 1996), depressive disorders (Hankin et al., 1998) as well as delinquency (Landsheer and 't Hart, 1999) and substance abuse and dependence (WHO International Consortium in Psychiatric Epidemiology, 2000). Adolescence is a period of dynamic (re)organization and formation of the neural circuitry underlying stress reactivity (Andersen, 2003; Romeo and McEwen, 2006). For example, the density of prefrontal cortex derived axon terminals decreases significantly between adolescence and adulthood (Cressman et al., 2010). A pre-adolescent increase in cortical gray matter is followed by a post-adolescent decrease (Giedd et al., 1999). Also, dopamine $\mathrm{D}_{1}$ and $\mathrm{D}_{2}$ receptors are overproduced prior to puberty and pruned back to adult levels thereafter in the striatum and prefrontal cortex (Gelbard et al., 1989; Teicher et al., 1995; Andersen et al., 2000). Therefore, stress during this period may have enduring consequences on mental health later in life via its effect on this process of structural and functional reorganization. However, the mechanisms underlying susceptibility to stress and manifestation of mental disorders during adolescence remain little understood.

We hypothesized that heightened sensitivity to stress during adolescence could reflect age-dependent differences in the expression of genes required for activity-dependent synaptic plasticity, and possibly, cognitive adaptation to stress. Brain-derived neurotrophic factor (BDNF) is among the major regulators of synaptic homeostasis, activity-dependent gene expression, and synaptic plasticity in the adult mammalian brain (Bramham and Messaoudi, 2005; Greenberg et al., 2009; Minichiello, 2009). Behavioral stress in animals is frequently correlated with decreased BDNF expression in the hippocampus and neocortex, while deletion 
of the BDNF gene is associated with heightened aggression to conspecifics, anxiety, and learning deficits, without affecting depression-like behavior in standard tests (Duman and Monteggia, 2006; Feder et al., 2009; Ito et al., 2011). Treatment with antidepressant drugs triggers enhanced BDNF gene expression and signaling that is required for the restorative behavioral effects in animal models of depression (Alme et al., 2007; Rantamaki et al., 2007; Adachi et al., 2008).

In the dentate gyrus, expression of the immediate early gene Arc (activity-regulated cytoskeleton associated protein) is required for formation of stable, transcription-dependent long-term potentiation (LTP) induced by brief intrahippocampal infusion of BDNF or by brief high-frequency stimulation (HFS) of the perforant pathway (Messaoudi et al., 2007; Bramham et al., 2010). Wibrand et al. (2006) further identified a panel of genes that are robustly co-up-regulated with Arc in dentate granule cells during both forms of LTP. These genes were subsequently found to be differentially regulated in brain region-specific manner following chronic antidepressant treatment in rats (Alme et al., 2007).

The social environment is an important source of stress (conflicts and tension) in everyday life of humans. To induce social stress in rats, we used the social defeat paradigm. Björkqvist (2001) suggested that the social defeat paradigm is an ecologically valid model to study the consequences of social stress, victimization, and social subjugation. Social defeat has been shown to induce long-lasting behavioral, physiological, and neurobiological changes. These include changes in social anxiety, heart rate, body temperature, activity as well as structural and functional changes in various brain neurocircuitries of rats (Meerlo et al., 1999; Buwalda et al., 2005). Therefore, we used social defeat on two consecutive days as a stressor in our experimental animals, which has been shown to induce reliable long-lasting effects on behavior and physiology (Meerlo et al., 1996).

We hypothesized that age-dependent differences in stress reactivity could reflect differences in the induction of BDNF-regulated and synaptic plasticity-linked immediate early genes. Directly after exposure to social defeat on two consecutive days, mRNA expression of BDNF (exon IV), Arc, Carp, and Tieg1 was determined by qPCR in tissue lysates obtained from prefrontal cortex, hippocampus, and nucleus accumbens.

The BDNF, Arc, Carp, and Tieg1 genes are strongly upregulated during BDNF-LTP in the dentate gyrus of the hippocampus (Wibrand et al., 2006). Gene expression of BDNF exon IV (i.e., exon III prior to Aid et al., 2007) was determined, since this exon is regulated as an immediate early gene and shows a peak level $1 \mathrm{~h}$ after stimulation (Lauterborn et al., 1996). Carp (calcium/calmodulin dependent protein kinase (CaMK)-related peptide), also known as ANIA-4 (Berke et al., 1998) is an alternative splice variant of the doublecortin-like kinase (DCLK) gene. Tieg1 (transforming growth factor- $\beta$ inducible early gene) is a member of the specificity protein/Kruppel-like factor (SP/KLF) family of zinc finger transcription factors (Subramaniam et al., 1995; Suske et al., 2005) and functions in enhancement of TGF- $\beta$-dependent gene expression (Johnsen et al., 2002).

The prefrontal cortex was chosen because of its major structural reorganization during adolescence (Kalsbeek et al., 1988) and its important role in emotional regulation (Quirk and Beer,
2006) and aggressive behavior (Blair, 2004; Siever, 2008). The prefrontal cortex is significantly involved in modulation of social behavior and in control of mood and motivational drive, functions that are important components of the personality of an individual (Miller, 2000; Miller and Cohen, 2001). Social defeat has been shown to have a major impact on hippocampal structure and functioning (Buwalda et al., 2005; Artola et al., 2006). In addition, we selected the nucleus accumbens because the ventral tegmental area-nucleus accumbens (VTA-NAcc) pathway has been shown to play a major role in the difference in resilience to social defeat (Berton et al., 2006; Krishnan et al., 2007).

In addition to age-dependent vulnerability to stress, humans exhibit large individual variations in vulnerability to stressinduced disorders and variability in measures of temperament and personality may largely predict this disease risk. Accordingly, variability in behaviorally relevant brain circuit functions due to differences in activity-dependent gene expression and synaptic plasticity may represent one of the causal factors determining the vulnerability to disease. In animals, behavioral differentiation in terms of coping style (personality) reflect trait characteristics that are stable over time (Koolhaas et al., 1999) and these characteristics are strongly correlated with a differentiation in the underlying neurobiological mechanisms (Veenema and Neumann, 2007; Koolhaas et al., 2010). For example, high levels of aggressive behavior are generally associated with low levels of brain serotonin and its metabolite 5-HIAA (De Boer et al., 2010; Koolhaas et al., 2010). Recent evidence suggests differences in molecular mechanisms of synaptic plasticity as well. For instance, non-aggressive, reactive coping male mice show a higher structural neuronal plasticity (Veenema and Neumann, 2007) and a higher hippocampal and prefrontal cortex expression of neuronal plasticity-related genes (Feldker et al., 2003).

To examine a possible link between individual differences in coping to social stress and expression of plasticity-linked genes, adult male wild-type Groningen (WTG) rats were individually characterized for their coping style using their displayed aggressiveness in a resident-intruder paradigm. Rats of this strain differ widely in the level of offensive aggression expressed toward an unfamiliar intruder male, ranging from no aggression at all (reactive coping) to very high levels of intense aggressive behavior (proactive coping). It has been shown that this broad individual variation in aggressiveness can be considered more generally as a variation in actively coping with environmental challenges (De Boer et al., 2003).

\section{MATERIALS AND METHODS ANIMALS}

Adolescent and adult male (WTG rats (Rattus Norvegicus; originally wild-trapped animals and bred under laboratory conditions for over 50 generations in our own facilities) were used. Animals were weaned at postnatal day 28 and housed in groups until the start of the experiment.

All animals were housed in temperature-controlled rooms $\left(21 \pm 2^{\circ} \mathrm{C}\right)$ under a 12 -h light:dark cycle (lights off at 1 p.m.) with food and water available ad libitum. Experiments were approved by the Groningen University Committee on Animal Experiments. 


\section{CHARACTERIZATION OF ADULT ANIMALS}

Adult animals were screened for the level of offensive aggressive behavior in a standard resident-intruder paradigm at an age of approximately 120 days. Animals were housed in large observation cages $(80 \mathrm{~cm} \times 55 \mathrm{~cm} \times 40 \mathrm{~cm})$ with a sterilized female (oviductligated) for 1 week to avoid social isolation and facilitate territorial behavior. After 1 week, the baseline level of aggressive behavior was tested in the resident-intruder test in the first half of the dark phase.

Before testing, the female was removed from the cage. During the first three tests an unfamiliar male conspecific (intruder) was introduced into the cage and the attack latency (time between introduction of the intruder and first attack) was scored. The intruder was removed after the first attack. If no attack occurred within 10 min the intruder was removed.

During the fourth test the full range of behaviors was scored during $10 \mathrm{~min}$. The frequency and duration of behavioral elements were scored. A total of 12 behavioral acts and postures were scored and grouped in five behavioral categories: (1) Offense (lateral threat, clinching, keep down, chasing, upright posture); (2) Social exploration (moving toward, nosing, investigating opponent, ano-genital sniffing, crawl over, attempted mount, social groom); (3) Non-social exploration (ambulation, rearing, sniffing, scanning, digging); (4) Inactivity (sitting, lying, immobile, freezing); (5) Grooming (washing, shaking, scratching).

The behavioral data of the last test and the four attack latencies were used to classify the offensive behavior of animals. Adult animals were divided in two groups: proactive $(<15 \%$ time spent on offensive behavior) and reactive ( $>65 \%$ time spent on offensive behavior). All adult animals were solitary housed after aggression screening.

\section{SOCIAL DEFEAT}

The experimental setup is illustrated in Figure 1. Half of the adolescent and adult (proactive and reactive) animals were subjected to social defeat on two consecutive days for $1 \mathrm{~h}$. Adolescent animals were defeated at postnatal day (pnd) 45 and 46, whereas adult animals were defeat at approximately pnd 140 . The resident rats were also WTG rats and were housed in a separate room in large cages $(80 \mathrm{~cm} \times 55 \mathrm{~cm} \times 40 \mathrm{~cm})$ with a female to stimulate territorial aggression. Prior to the experimental procedure, females were removed from the resident's cage. Residents were trained to attack a naïve intruder, only residents that attacked within 2 min were used for the experiment. By using animals with a more or less similar readiness to attack we tried to avoid variation in attack intensity.

Experimental animals were moved to the room of the residents. Animals in the defeat groups were introduced in the cage of the resident and were attacked for $15 \mathrm{~min}$. Thereafter animals were placed in a wire mesh cage $(30 \mathrm{~cm} \times 15 \mathrm{~cm} \times 15 \mathrm{~cm})$ in the cage of the resident for $45 \mathrm{~min}$. In this way, animals were protected from further attacks and injury, but remained in visual, auditory, and olfactory contact with the resident. This period of psychosocial stress is known to be highly stressful (Tornatzky and Miczek, 1994). On the second day of the defeats, animals were directly exposed to another aggressive resident for $5 \mathrm{~min}$ and placed in the wire mesh cage for $55 \mathrm{~min}$. Defeats took place in the first half of the dark phase. Brain material was collected immediately after the end of the second defeat. The control animals were directly taken from the home cage and were sacrificed at the same time as defeat animals.

\section{COLLECTION OF BRAIN MATERIAL}

Directly after the end of the second defeat, rats were anesthetized by $\mathrm{CO}_{2}$, decapitated, and the brain was removed. The

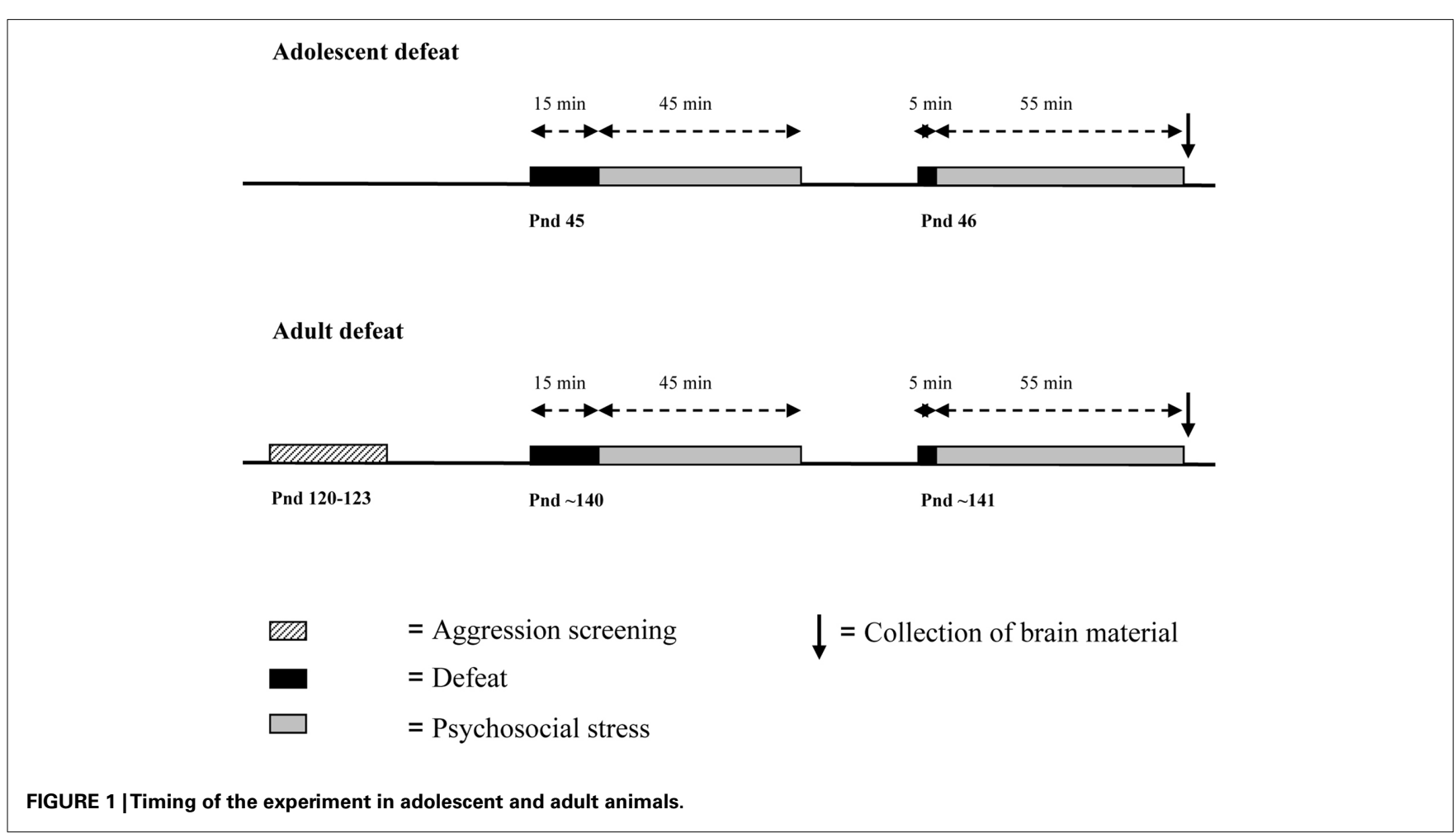


prefrontal cortex, hippocampus, and nucleus accumbens were rapidly dissected on ice. The tissue was immediately frozen in $\mathrm{N}_{2}$ and stored at $-80^{\circ} \mathrm{C}$. The $1 \mathrm{~h}$ time point after the start of the second defeat was chosen because previous studies indicated that the mRNAs under study are all induced within $1 \mathrm{~h}$ after BDNF infusion into the dentate gyrus (Dagestad et al., 2006; Wibrand et al., 2006).

\section{RNA ISOLATION AND cDNA PREPARATION}

Total RNA was isolated using the mirVana ${ }^{\mathrm{TM}}$ PARIS $^{\mathrm{TM}}$ miRNA isolation kit (Ambion, AM1556) according to the manual. DNAse treatment was carried out to remove genomic DNA contamination prior to cDNA synthesis (Ambion, EN0521). The yield and quality of the RNA were determined by measuring the absorbance at 260/280 nm. Single-stranded cDNA was synthesized from $2 \mu \mathrm{g}$ of total RNA according to the MMLV reverse transcriptase kit instructions (Ambion, AM2043).

\section{REAL-TIME QUANTITATIVE PCR}

Real-time quantitative PCR was performed on a Roche LightCycler $^{\circledR} 480$ II (Roche Applied Science) using cDNA from individual animals. cDNA corresponding to $10 \mathrm{ng}$ total RNA was analyzed in $25 \mu \mathrm{l}$ reactions using $2 \times$ TaqMan PCR mix (Applied Biosystems). PCR quantification was performed in triplicate and the relative standard curve method to determine gene expression levels was used for each animal using the Roche LightCycler ${ }^{\circledR} 480$ Software (release-1.5.0 SP4)

Three housekeeping genes were analyzed (hrpt1, ubiquitin B, and cyclophilin A) and gene expression levels for Arc, BDNF, Carp, and Tiegl were determined.

Commercially designed TaqMan ${ }^{\circledR}$ Gene expression assays were as follows (genes in parentheses): Rn00571208_g1 (Arc), Rn01484927_m1 (BDNF exon IV), Rn00572049_m1 (Carp), Rn00579697_m1 (Tieg1), Rn00690933_m1 (cyclophilin A), Rn03062801_g1 (ubiquitin B), and Rn01527840_m1 (Hrpt1). Hrpt1 expression was used as endogenous reference for the adolescent samples and adult gene expression was normalized to ubiquitin expression. The relative gene expression levels are presented as fold change based on the average group gene expression level of adolescent control and adult (reactive) control animals.

\section{STATISTICS}

Results are presented as mean \pm SEM. Statistical analysis was performed using SPSS (version 16). Data of the adolescent social defeat were analyzed using a Student's $t$-test. Adult data were analyzed using a two-way ANOVA with coping style and defeat as between subject factors. A $p$-value less than 0.05 was considered to be statistically significant.

\section{RESULTS}

\section{SOCIAL DEFEAT DURING ADOLESCENCE LEADS TO BRAIN} REGION-SPECIFIC UPREGULATION OF BDNF-LTP RELATED IMMEDIATE

\section{EARLY GENES}

Quantitative real-time PCR was used to determine changes in the level of mRNA expression of BDNF-LTP related genes in the prefrontal cortex, hippocampus, and nucleus accumbens after adolescent social defeat. In the prefrontal cortex (Figure 2A), the level of Arc $(p=0.04)$ and Tieg1 $(p=0.04)$ were significantly

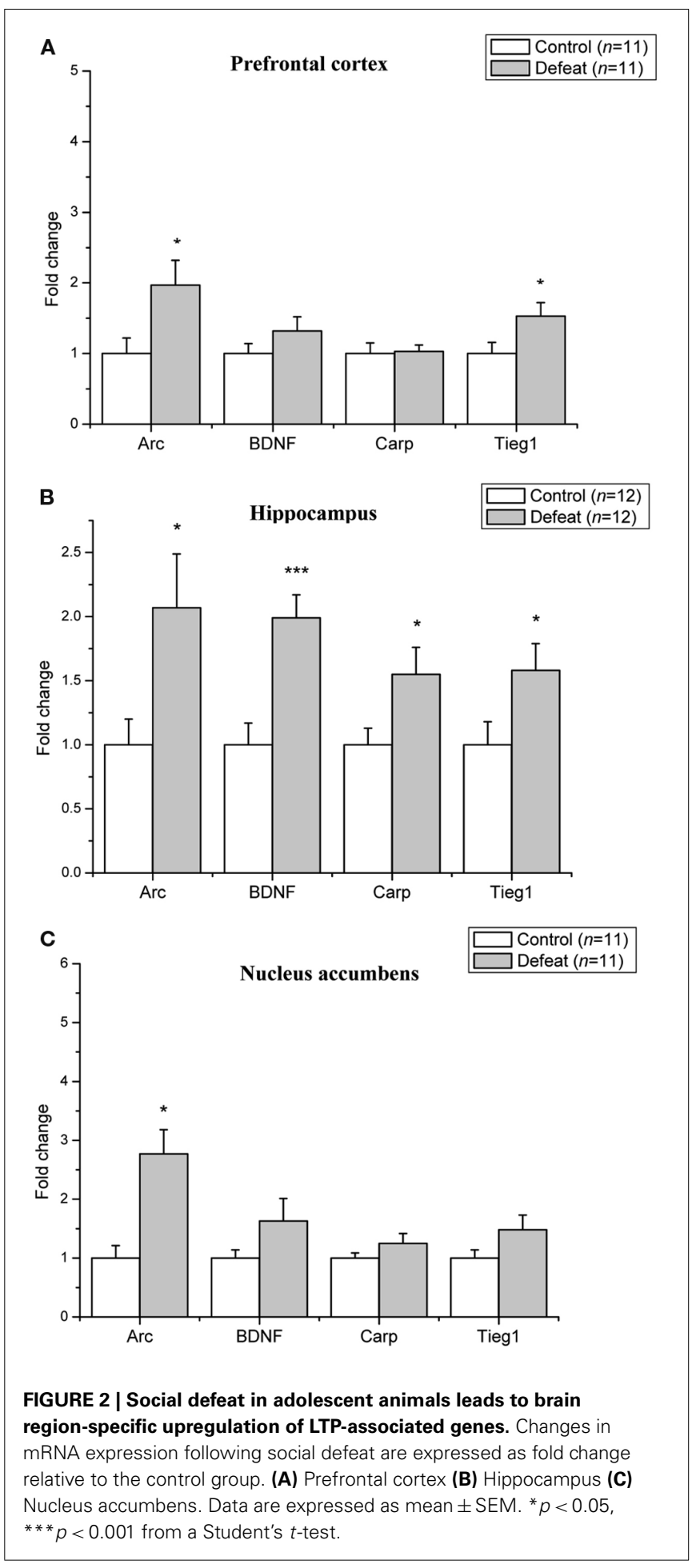

up-regulated by social defeat compared to control animals, whereas the levels of BDNF and Carp did not differ significantly between control and defeat animals. In the hippocampus (Figure 2B), the levels of Arc $(p=0.02), \operatorname{BDNF}(p<0.001)$, Carp $(p=0.03)$, and Tieg1 $(p=0.04)$ were all increased in social defeat animals. In the nucleus accumbens (Figure 2C), the level of Arc 
was up-regulated three-fold in defeat animals $(p=0.001)$, BDNF, Carp, and Tieg1 levels did not differ between groups.

\section{SOCIAL DEFEAT DURING ADULTHOOD AND EFFECT OF COPING STYLE}

Proactive and reactive animals were divided in control and defeat groups. A justification of the composition of the four experimental groups and the behavioral profile is given in Table 1 . The data represent the time spent on five different behavioral categories and the attack latency during the 10-min offensive aggression test. There are no statistically significant differences between the various control and defeat groups.

The level of mRNA expression of BDNF-LTP related genes in adult animals is depicted in Figure 3. The level of Arc mRNA expression was significantly elevated in the prefrontal cortex $\left(F_{1,19}=9.29, p=0.007\right.$; Figure $\left.3 \mathrm{~A}\right)$ and nucleus accumbens $\left(F_{1,18}=7.26, p=0.015\right.$; Figure $\left.3 \mathrm{C}\right)$ of defeated animals, whereas Arc mRNA levels were not affected in the hippocampus (Figure 3B). BDNF mRNA was significantly increased in the nucleus accumbens of defeat rats $\left(F_{1,19}=5.00, p=0.04\right)$. A trend toward a significant interaction between the coping style of animals and defeat was seen in the level of BDNF mRNA in the nucleus accumbens $\left(F_{1,19}=3.23, p=0.09\right)$ was found. Tieg1 mRNA expression levels were increased only in the nucleus accumbens $\left(F_{1,19}=5.07, p=0.04\right)$. The level of Carp was not affected by social defeat in any of the examined brain regions. In the hippocampus, none of immediate early genes examined were induced in adult proactive and reactive rats, whereas all were induced following social defeat in adolescent rats.

\section{DISCUSSION}

This study shows that adolescent and adult social stress leads to brain region-specific upregulation of genes associated with BDNFinduced LTP. There is a major age-dependent effect of social defeat on gene expression in the hippocampus. Arc, BDNF, Carp, and Tieg1 were all up-regulated by social stress in the hippocampus of adolescent animals, whereas in adults none of these genes were induced. Similar age-dependent effects have been demonstrated by Toth et al. (2008). In young rats, BDNF protein levels in the hippocampus were increased after chronic mild stress, whereas decreased levels were found in the hippocampus of adult rats (Toth et al., 2008). In addition, in young, but not adult, rats hippocampal BDNF protein induces prolonged elevations in corticosterone secretion (Taliaz et al., 2011).

In the prefrontal cortex of adolescent animals Arc and Tieg1 were up-regulated after defeat. In contrast to the hippocampus, the prefrontal cortex appears to be more affected by social defeat in adult animals. Gene expression levels of Arc are almost two-fold higher in adult defeated animals compared to adolescent defeated animals. Several studies reported an induction of Arc mRNA in the prefrontal cortex from both acute and chronic stress paradigms as well (Ons et al., 2004, 2010; Mikkelsen and Larsen, 2006).

In the nucleus accumbens, Arc gene expression was markedly increased after social defeat both in adolescent and in adult animals. BDNF was significantly up-regulated only in adult defeated animals. This age related difference corresponds with reports on late developmental changes in neural systems in the nucleus accumbens (Tarazi et al., 1998, 1999). However these findings are not unanimous. For example, Leslie et al. (1991) did not show a change during adolescence in dopamine receptor density (Leslie et al., 1991).

The results demonstrate region-specific and age-dependent effects of social stress on immediately early genes linked to LTP and BDNF signaling. In the hippocampus, the striking age-dependent effects suggest that social defeat mobilizes a strong immediate early gene response that is absent in adult animals. This raises the possibility that hippocampal long-term synaptic plasticity is selectively engaged in social stress during adolescence. The function of the gene expression in the hippocampus is not known; it could reflect a transient adaptive response (resilience) or a step toward the experience-dependent maturation of the hippocampal response to social defeat.

It is often assumed that adolescents are more vulnerable to social stress, since the prefrontal cortex and the hippocampus are still undergoing structural reorganization during this developmental period (Kalsbeek et al., 1988; Andersen et al., 2000; Andersen, 2003). Based on the current data, we can indeed conclude that adolescent social stress is qualitatively different from adult social stress in the expression of synaptic plasticity-related genes.

We expected baseline differences in the level of genes related to BDNF-LTP in adult animals with different coping strategies. It is known that reactive coping male mice show a higher expression of several genes coding for cytoskeletal and signal transduction proteins in the hippocampus compared to proactive coping mice (Feldker et al., 2003). In addition, the intra- and infra-pyramidal mossy fibers terminal fields in the hippocampus of reactive coping mice are larger (Sluyter et al., 1994). In the rat however, these observations are not supported by a difference in baseline gene expression profiles.

No difference was found in the level of gene expression between proactive and reactive coping after social defeat. However, a trend

Table 1 | Behavioral profile (attack latency in seconds and percentage time spent on the six distinct behavioral categories during a 10-min resident-intruder aggression test) of the four different groups used for the study.

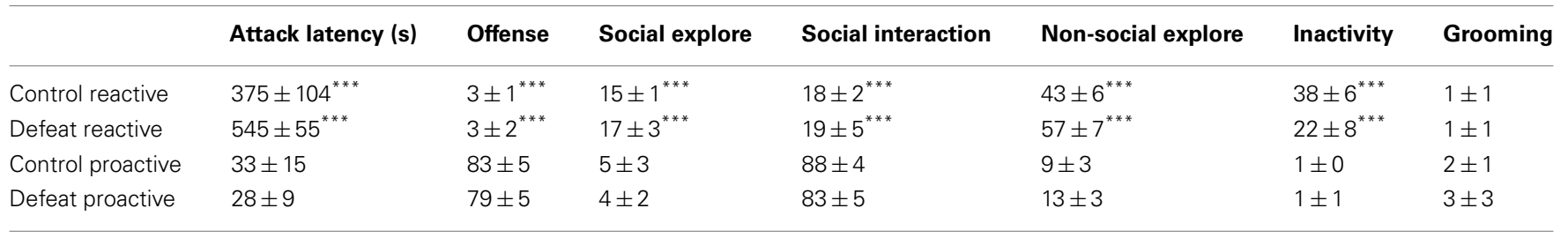

Data are expressed as mean \pm SEM. ${ }^{* *} p<0.001$ two-way ANOVA. 


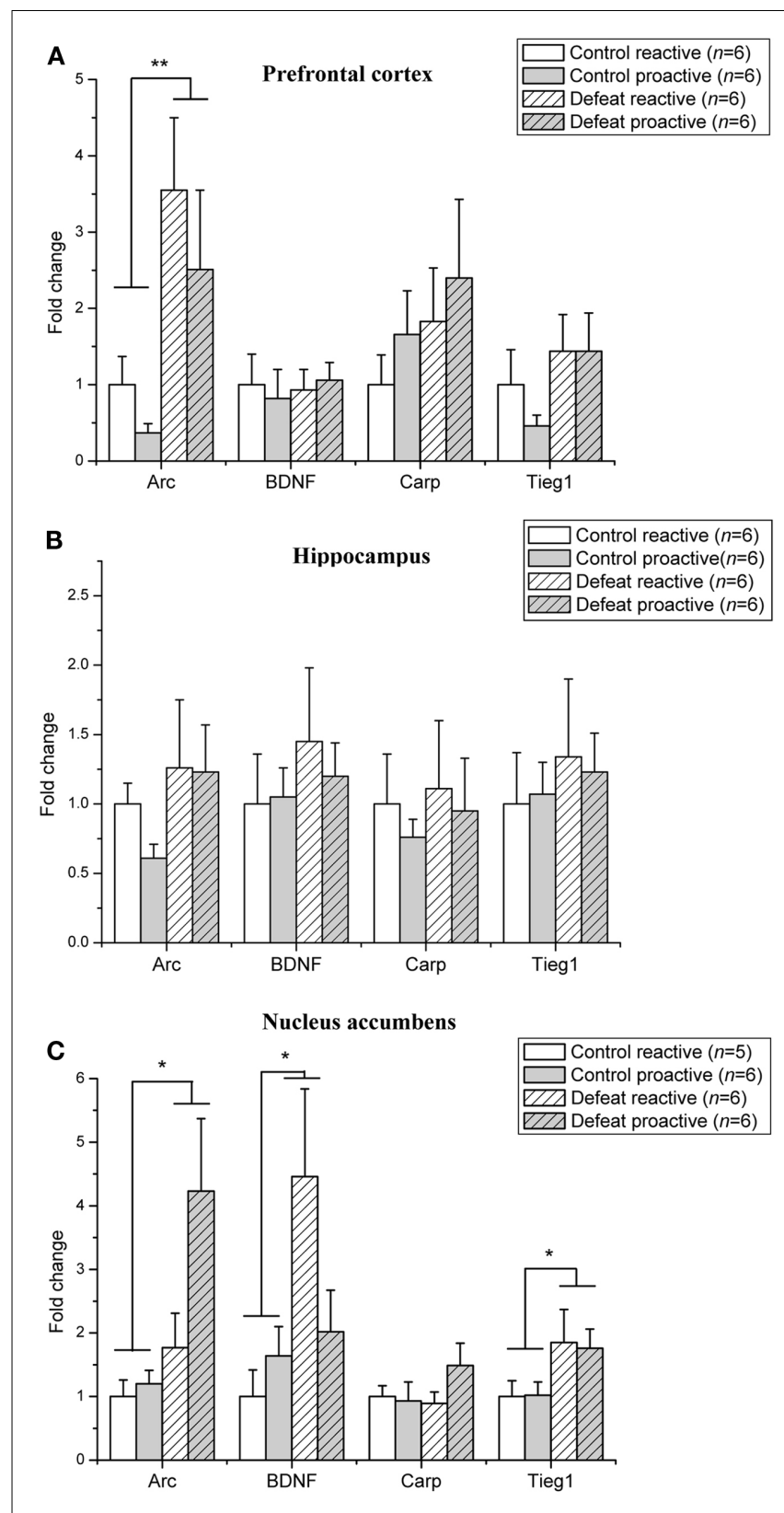

FIGURE 3 | Social defeat induces brain region-specific upregulation of LTP-associated genes in adult proactive and reactive animals. Changes in mRNA expression following social defeat are expressed as fold change relative to the reactive control group. (A) Prefrontal cortex (B) Hippocampus (C) Nucleus accumbens. Data are expressed as mean \pm SEM. ${ }^{*} p<0.05,{ }^{* *} p<0.01$ from two-way ANOVA.

toward a differential effect of defeat on proactive and reactive coping animals was found in BDNF mRNA in the nucleus accumbens. Reactive animals show increased levels of BDNF mRNA after defeat, whereas proactive BDNF mRNA levels are comparable to levels of control animals.

The differential BDNF mRNA expression after defeat in reactive and proactive animals might be associated with resilience to social defeat. Krishnan et al. (2007) showed that BDNF mRNA levels in the nucleus accumbens of mice subjected to social defeat are equal to control animals. However, in a group of susceptible mice BDNF protein levels are increased, whereas BDNF levels in unsusceptible mice are unaffected (Krishnan et al., 2007). Manipulation of BDNF gene expression levels in the mesolimbic dopamine pathway by local deletion of the BDNF gene reduces the longterm neural and behavioral response to social defeat stress similar to effects produced by antidepressant treatment (Berton et al., 2006).

Arc is a key effector protein for BDNF-induced LTP, but Arc is multifunctional protein required for other forms of synaptic plasticity such as long-term depression and homeostatic scaling (Rial Verde et al., 2006; Shepherd et al., 2006; Bramham et al., 2008; Waung et al., 2008) as well. Homeostatic plasticity may compensate LTP and LTD by scaling neuronal output without changing the relative strength of individual synapses (Shepherd et al., 2006). Synaptic plasticity in the developing visual cortex is an example of this homeostatic plasticity. Arc appears to be required for the experience-dependent processes that normally establish and modify synaptic connections in the visual cortex (McCurry et al., 2010). Arc induction after social defeat might induce a similar process of homeostatic plasticity.

It is unknown what mechanism determines whether Arc is selectively engaged in homeostatic plasticity, LTP or LTD. Social defeat not only reduces LTP in rats, but also enhances long-term depression (LTD) 7-9 months after repeated defeat experience (Kole et al., 2004; Artola et al., 2006). Therefore, the increased level of Arc found after social defeat in the current study might be functionally involved in the process of homeostatic plasticity.

One confounding factor may be that the current social defeat procedure includes individual housing after social defeat. Social isolation appears to be an important factor in the long-term effects of defeat since social housing has been shown to reduce the impact of social defeat (Ruis et al., 1999; De Jong et al., 2005). Solitary housing in itself affects LTP and LTD; LTP is higher in animals that are housed in an enriched environment compared to individually housed animals (Artola et al., 2006).

Other possible confounding factors are false-negative results due to the temporal dynamics of gene expression after social defeat. The fact that all genes were up-regulated in the hippocampus of adolescent rats makes it unlikely that there are false-negatives in the gene expression levels of other brain areas of adolescent and adult animals.

The temporal dynamics of mRNA expression following BDNFLTP and HFS LTP has been studied by Wibrand et al. (2006) using in situ hybridization. They showed that the kinetics of mRNA was rapid ( $40 \mathrm{~min}$ following post-HFS) and sustained ( $3 \mathrm{~h}$ post BDNF) in the dentate gyrus granule cells (Wibrand et al., 2006). Based on this time course of gene expression it is unlikely that the chosen time point resulted in false-negative effects of social defeat.

We did not dissociate between sub-regions of the hippocampus, prefrontal cortex, and nucleus accumbens. However, there may be a difference in gene expression levels in different regions of the hippocampus. For example, Grønli et al. (2006) showed that chronic mild stress inhibits BDNF protein expression in the dentate gyrus, but not in the hippocampus proper and 
immobilization stress in rats is associated with greater impairments in BDNF mRNA expression in the dentate gyrus compared to the cornus ammonis (CA) region (Smith et al., 1995). Similarly, the effects of social defeat stress on gene expression may differ between subdivisions of the prefrontal cortex and nucleus accumbens. Whether subregional differences in gene expression in response to social defeat stress exist

\section{REFERENCES}

Adachi, M., Barrot, M., Autry, A. E., Theobald, D., and Monteggia, L. M. (2008). Selective loss of brainderived neurotrophic factor in the dentate gyrus attenuates antidepressant efficacy. Biol. Psychiatry 63, 642-649.

Aid, T., Kazantseva, A., Piirsoo, M., Palm, K., and Timmusk, T. (2007). Mouse and rat BDNF gene structure and expression revisited. J. Neurosci. Res. 85, 525-535.

Alme, M. N., Wibrand, K., Dagestad, G., and Bramham, C. R. (2007). Chronic fluoxetine treatment induces brain region-specific upregulation of genes associated with BDNF-induced long-term potentiation. Neural Plast. 2007, 26496.

Andersen, S. L. (2003). Trajectories of brain development: point of vulnerability or window of opportunity? Neurosci. Biobehav. Rev. 27, 3-18.

Andersen, S. L., Thompson, A. T., Rutstein, M., Hostetter, J. C., and Teicher, M. H. (2000). Dopamine receptor pruning in prefrontal cortex during the periadolescent period in rats. Synapse 37, 167-169.

Artola, A., Von Frijtag, J. C., Fermont, P. C., Gispen, W. H., Schrama, L. H., Kamal, A., and Spruijt, B. M. (2006). Long-lasting modulation of the induction of LTD and LTP in rat hippocampal CAl by behavioural stress and environmental enrichment. Eur. J. Neurosci. 23, 261-272.

Berke, J. D., Paletzki, R. F., Aronson, G. J., Hyman, S. E., and Gerfen, C. R. (1998). A complex program of striatal gene expression induced by dopaminergic stimulation. J. Neurosci. 18, 5301-5310.

Bernstein, D. P., Cohen, P., Skodol, A., Bezirganian, S., and Brook, J. S. (1996). Childhood antecedents of adolescent personality disorders. Am. J. Psychiatry 153, 907-913.

Berton, O., Mcclung, C. A., Dileone, R. J., Krishnan, V., Renthal, W., Russo, S. J., Graham, D., Tsankova, N. M., Bolanos, C. A., Rios, M., Monteggia, L. M., Self, D. W., and Nestler, E. J. (2006). Essential role of BDNF in the mesolimbic dopamine pathway in social defeat stress. Science 311, 864-868.

Björkqvist, K. (2001). Social defeat as a stressor in humans. Physiol. Behav. 73, 435-442.

Blair, R. J. R. (2004). The roles of orbital frontal cortex in the modulation of antisocial behavior. Brain Cogn. 55, 198-208.

Bramham, C. R., Alme, M. N., Bittins, M., Kuipers, S. D., Nair, R. R., Pai, B., Panja, D., Schubert, M., Soule, J., Tiron, A., and Wibrand, K. (2010). The arc of synaptic memory. Exp. Brain Res. 200, 125-140.

Bramham, C. R., and Messaoudi, E. (2005). BDNF function in adult synaptic plasticity: the synaptic consolidation hypothesis. Prog. Neurobiol. 76, 99-125.

Bramham, C. R., Worley, P. F., Moore, M. J., and Guzowski, J. F. (2008). The immediate early gene arc/arg3.1: regulation, mechanisms, and function. J. Neurosci. 28, 11760-11767.

Buwalda, B., Kole, M. H. P., Veenema, A. H., Huininga, M., De Boer, S. F., Korte, S. M., and Koolhaas, J. M. (2005). Long-term effects of social stress on brain and behavior: a focus on hippocampal functioning. Neurosci. Biobehav. Rev. 29, 83-97.

Cressman, V. L., Balaban, J., Steinfeld, S., Shemyakin, A., Graham, P., Parisot, N., and Moore, H. (2010). Prefrontal cortical inputs to the basal amygdala undergo pruning during late adolescence in the rat. J. Comp. Neurol. 518, 2693-2709.

Dagestad, G., Kuipers, S. D., Messaoudi, E., and Bramham, C. R. (2006). Chronic fluoxetine induces region-specific changes in translation factor eIF4E and eEF2 activity in the rat brain. Eur. J. Neurosci. 23, 2814-2818.

De Boer, S., Caramaschi, D., Natarajan, D., and Koolhaas, J. (2010). The vicious cycle towards violence: focus on the negative feedback mechanisms of brain serotonin neurotransmission. Front. Behav. Neurosci. 3:52. doi:10.3389/neuro.08.052.2009

De Boer, S. F., Van der Vegt, B. J., and Koolhaas, J. M. (2003). Individual variation in aggression of feral rodent strains: a standard for the

needs to be determined in future experiments using in situ hybridization.

\section{ACKNOWLEDGMENTS}

This research was supported by NWO via the European Collaborative Research (EUROCORES) program EuroSTRESS, of the European Science Foundation (ESF).

genetics of aggression and violence? Behav. Genet. 33, 485-501.

De Jong, J. G., Van der Vegt, B. J., Buwalda, B., and Koolhaas, J. M. (2005). Social environment determines the long-term effects of social defeat. Physiol. Behav. 84, 87-95.

Duman, R. S., and Monteggia, L. M. (2006). A neurotrophic model for stress-related mood disorders. Biol. Psychiatry 59, 1116-1127.

Feder, A., Nestler, E. J., and Charney, D. S. (2009). Psychobiology and molecular genetics of resilience. Nat. Rev. Neurosci. 10, 446-457.

Feldker, D. E., Datson, N. A., Veenema, A. H., Meulmeester, E., De Kloet, E. R., and Vreugdenhil, E. (2003). Serial analysis of gene expression predicts structural differences in hippocampus of long attack latency and short attack latency mice. Eur. J. Neurosci. 17, 379-387.

Gelbard, H. A., Teicher, M. H., Faedda, G., and Baldessarini, R. J. (1989). Postnatal development of dopamine $\mathrm{D} 1$ and D2 receptor sites in rat striatum. Brain Res. Dev. Brain Res. 49, 123-130.

Giedd, J. N., Blumenthal, J., Jeffries, N. O., Castellanos, F. X., Liu, H., Zijdenbos, A., Paus, T., Evans, A. C., and Rapoport, J. L. (1999). Brain development during childhood and adolescence: a longitudinal MRI study. Nat. Neurosci. 2, 861-863.

Greenberg, M. E., Xu, B., Lu, B. and Hempstead, B. L. (2009). New insights in the biology of BDNF synthesis and release: implications in CNS function. J. Neurosci. 29, 12764-12767.

Grønli, J., Bramham, C., Murison, R. Kanhema, T., Fiske, E., Bjorvatn, B., Ursin, R., and Portas, C. M. (2006). Chronic mild stress inhibits BDNF protein expression and CREB activation in the dentate gyrus but not in the hippocampus proper. Pharmacol. Biochem. Behav. 85, 842-849.

Hankin, B. L., Abramson, L. Y., Moffitt, T. E., Silva, P. A., Mcgee, R., and Angell, K. E. (1998). Development of depression from preadolescence to young adulthood: emerging gender differences in a 10-year longitudinal study. J. Abnorm. Psychol. 107, 128-140.
Ito, W., Chehab, M., Thakur, S., Li, J., and Morozov, A. (2011). BDNFrestricted knockout mice as an animal model for aggression. Genes Brain Behav. 10, 365-374.

Johnsen, S. A., Subramaniam, M., Katagiri, T., Janknecht, R., and Spelsberg, T. C. (2002). Transcriptional regulation of Smad2 is required for enhancement of TGFbeta/Smad signaling by TGFbeta inducible early gene. J. Cell. Biochem. 87, 233-241.

Kalsbeek, A., Voorn, P., Buijs, R. M., Pool, C. W., and Uylings, H. B. (1988). Development of the dopaminergic innervation in the prefrontal cortex of the rat. J. Comp. Neurol. 269, 58-72.

Kole, M. H. P., Costoli, T., Koolhaas, J. M., and Fuchs, E. (2004). Bidirectional shift in the cornuammonis 3 pyramidal dendritic organization following brief stress. Neuroscience $125,337-347$.

Koolhaas, J. M., De Boer, S. F., Coppens, C. M., and Buwalda, B. (2010). Neuroendocrinology of coping styles: towards understanding the biology of individual variation. Front. Neuroendocrinol. 31:307-321.

Koolhaas, J. M., Korte, S. M., De Boer, S. F., Van Der Vegt, B. J., Van Reenen, C. G., Hopster, H., De Jong, I. C., Ruis, M. A. W., and Blokhuis, H. J. (1999). Coping styles in animals current status in behavior and stressphysiology. Neurosci. Biobehav. Rev. 23, 925-935.

Krishnan, V., Han, M.-H., Graham, D. L., Berton, O., Renthal, W., Russo, S. J., Laplant, Q., Graham, A., Lutter, M., Lagace, D. C., Ghose, S., Reister, R., Tannous, P., Green, T. A., Neve, R. L., Chakravarty, S., Kumar, A., Eisch, A. J., Self, D. W., Lee, F. S., Tamminga, C. A., Cooper, D. C., Gershenfeld, H. K., and Nestler, E. J. (2007). Molecular adaptations underlying susceptibility and resistance to social defeat in brain reward regions. Cell 131, 391-404.

Landsheer, J. A., and 't Hart, H. (1999). Age and adolescent delinquency the changing relationship among age, delinquent attitude, and delinquent activity. Crim. Justice Behav. 26, 373-388. 
Lauterborn, J. C., Rivera, S., Stinis, C. T., Hayes, V. Y., Isackson, P. J., and Gall, C. M. (1996). Differential effects of protein synthesis inhibition on the activity-dependent expression of BDNF transcripts: evidence for immediate-early gene responses from specific promoters. J. Neurosci. 16, 7428-7436.

Leslie, C. A., Robertson, M. W., Cutler, A. J., and Bennett, J. P. Jr. (1991). Postnatal development of D1 dopamine receptors in the medial prefrontal cortex, striatum and nucleus accumbens of normal and neonatal 6-hydroxydopamine treated rats: a quantitative autoradiographic analysis. Brain Res. Dev. Brain Res. 62, 109-114.

McCurry, C. L., Shepherd, J. D., Tropea, D., Wang, K. H., Bear, M. F., and Sur, M. (2010). Loss of Arc renders the visual cortex impervious to the effects of sensory experience or deprivation. Nat. Neurosci. 13, 450-457.

Meerlo, P., Overkamp, G. J., Daan, S., Van Den Hoofdakker, R. H., and Koolhaas, J. M. (1996). Changes in behaviour and body weight following a single or double social defeat in rats. Stress 1, 21-32.

Meerlo, P., Sgoifo, A., De Boer, S. F., and Koolhaas, J. M. (1999). Long-lasting consequences of a social conflict in rats: behavior during the interaction predicts subsequent changes in daily rhythms of heart rate, temperature, and activity. Behav. Neurosci. 113, 1283-1290.

Messaoudi, E., Kanhema, T., Soule, J., Tiron, A., Dagyte, G., Da Silva, B., and Bramham, C. R. (2007). Sustained Arc/Arg3.1 synthesis controls long-term potentiation consolidation through regulation of local actin polymerization in the dentate gyrus in vivo. J. Neurosci. 27, 10445-10455.

Mikkelsen, J. D., and Larsen, M. H. (2006). Effects of stress and adrenalectomy on activity-regulated cytoskeleton protein (Arc) gene expression. Neurosci. Lett. 403, 239-243.

Miller, E. K. (2000). The prefrontal cortex and cognitive control. Nat. Rev. Neurosci. 1, 59-65.

Miller, E. K., and Cohen, J. D. (2001). An integrative theory of prefrontal cortex function. Annu. Rev. Neurosci. 24, 167-202.
Minichiello, L. (2009). TrkB signalling pathways in LTP and learning. Nat. Rev. Neurosci. 10, 850-860.

Ons, S., Marti, O., and Armario, A. (2004). Stress-induced activation of the immediate early gene Arc (activity-regulated cytoskeletonassociated protein) is restricted to telencephalic areas in the rat brain: relationship to c-fos mRNA. J. Neurochem. 89, 1111-1118.

Ons, S., Rotllant, D., Marin-Blasco, I. J., and Armario, A. (2010). Immediateearly gene response to repeated immobilization: Fos protein and arc mRNA levels appear to be less sensitive than c-fos mRNA to adaptation. Eur. J. Neurosci. 31, 2043-2052.

Quirk, G. J., and Beer, J. S. (2006). Prefrontal involvement in the regulation of emotion: convergence of rat and human studies. Curr. Opin. Neurobiol. 16, 723-727.

Rantamaki, T., Hendolin, P., Kankaanpaa, A., Mijatovic, J., Piepponen, P., Domenici, E., Chao, M. V., Mannisto, P. T., and Castren, E. (2007). Pharmacologically diverse antidepressants rapidly activate brainderived neurotrophic factor receptor TrkB and induce phospholipaseCgamma signaling pathways in mouse brain. Neuropsychopharmacology 32, 2152-2162.

Rial Verde, E. M., Lee-Osbourne, J., Worley, P. F., Malinow, R., and Cline, H. T. (2006). Increased expression of the immediate-early gene $\operatorname{arc} / \arg 3.1$ reduces AMPA receptor-mediated synaptic transmission. Neuron 52, 461-474.

Romeo, R. D., and McEwen, B. S. (2006). Stress and the adolescent brain. Ann. N. Y. Acad. Sci. 1094, 202-214.

Ruis, M. A., Te Brake, J. H., Buwalda, B., De Boer, S. F., Meerlo, P., Korte, S. M., Blokhuis, H. J., and Koolhaas, J. M. (1999). Housing familiar male wildtype rats together reduces the longterm adverse behavioural and physiological effects of social defeat. Psychoneuroendocrinology 24, 285-300.

Shepherd, J. D., Rumbaugh, G., Wu, J., Chowdhury, S., Plath, N., Kuhl, D., Huganir, R. L., and Worley, P. F. (2006). Arc/Arg3.1 mediates homeostatic synaptic scaling of AMPA receptors. Neuron 52, 475-484.

Siever, L. J. (2008). Neurobiology of aggression and violence. Am. J. Psychiatry 165, 429-442.
Sluyter, F., Jamot, L., Van Oortmerssen, G. A., and Crusio, W. E. (1994). Hippocampal mossy fiber distributions in mice selected for aggression. Brain Res. 646, 145-148.

Smith, M. A., Makino, S., Kvetnansky, R., and Post, R. M. (1995). Stress and glucocorticoids affect the expression of brain-derived neurotrophic factor and neurotrophin-3 mRNAs in the hippocampus. J. Neurosci. 15, 1768-1777.

Subramaniam, M., Harris, S. A., Oursler, M. J., Rasmussen, K., Riggs, B. L., and Spelsberg, T. C. (1995). Identification of a novel TGF-beta-regulated gene encoding a putative zinc finger protein in human osteoblasts. Nucleic Acids Res. 23, 4907-4912.

Suske, G., Bruford, E., and Philipsen, S. (2005). Mammalian SP/KLF transcription factors: bring in the family. Genomics 85, 551-556.

Taliaz, D., Loya, A., Gersner, R., Haramati, S., Chen, A., and Zangen, A (2011). Resilience to chronic stress is mediated by hippocampal brainderived neurotrophic factor. J. Neurosci. 31, 4475-4483.

Tarazi, F. I., Tomasini, E. C., and Baldessarini, R. J. (1998). Postnatal development of dopamine D4-like receptors in rat forebrain regions: comparison with D2-like receptors. Brain Res. Dev. Brain Res. 110 227-233.

Tarazi, F. I., Tomasini, E. C., and Baldessarini, R. J. (1999). Postnatal development of dopamine D1-like receptors in rat cortical and striatolimbic brain regions: an autoradiographic study. Dev. Neurosci. 21, 43-49.

Teicher, M. H., Andersen, S. L., and Hostetter, J. C. Jr. (1995). Evidence for dopamine receptor pruning between adolescence and adulthood in striatum but not nucleus accumbens. Brain Res. Dev. Brain Res. 89, 167-172.

Tornatzky, W., and Miczek, K. A. (1994). Behavioral and autonomic responses to intermittent social stress: differential protection by clonidine and metoprolol. Psychopharmacology (Berl.) 116, 346-356.

Toth, E., Gersner, R., Wilf-Yarkoni, A., Raizel, H., Dar, D. E., Richter-Levin, G., Levit, O., and Zangen, A. (2008). Age-dependent effects of chronic stress on brain plasticity and depressive behavior. J. Neurochem. 107, 522-532.

Veenema, A. H., and Neumann, I. D. (2007). Neurobiological mechanisms of aggression and stress coping: a comparative study in mouse and rat selection lines. Brain Behav. Evol. 70, 274-285.

Waung, M. W., Pfeiffer, B. E., Nosyreva, E. D., Ronesi, J. A., and Huber K. M. (2008). Rapid translation of Arc/Arg3.1 selectively mediates mGluR-dependent LTD through persistent increases in AMPAR endocytosis rate. Neuron 59, 84-97.

WHO International Consortium in Psychiatric Epidemiology. (2000). Cross-national comparisons of the prevalences and correlates of menta disorders. Bull. World Health Organ. 78, 413-426.

Wibrand, K., Messaoudi, E., Havik, B., Steenslid, V., Lovlie, R., Steen, V. M., and Bramham, C. R. (2006). Identification of genes co-upregulated with Arc during BDNF-induced longterm potentiation in adult rat dentate gyrus in vivo. Eur. J. Neurosci. 23, 1501-1511.

Conflict of Interest Statement: The authors declare that the research was conducted in the absence of any commercial or financial relationships that could be construed as a potential conflict of interest.

Received: 15 June 2011; accepted: 11 October 2011; published online: 02 November 2011.

Citation: Coppens CM, Siripornmongcolchai $T$, Wibrand $K$, Alme $M N$, Buwalda B, de Boer SF, Koolhaas JM and Bramham CR (2011) Social defeat during adolescence and adulthood differentially induce BDNF-regulated immediate early genes. Front. Behav. Neurosci. 5:72. doi: 10.3389/fnbeh.2011.00072

Copyright (c) 2011 Coppens, Siripornmongcolchai, Wibrand, Alme, Buwalda, de Boer, Koolhaas and Bramham. This is an open-access article subject to a nonexclusive license between the authors and Frontiers Media SA, which permits use, distribution and reproduction in other forums, provided the original authors and source are credited and other Frontiers conditions are complied with. 